\title{
Poetry, Poetics, and Politics in the Nile Sonnets
}

\author{
Mona Salah El-Din Hassanein \\ Lecturer in English Literature \\ English Department \\ Faculty of Education \\ Ain Shams University
}

\section{Abstract:}

Arising from a poetry-writing contest on the subject of the Nile, the Nile Sonnets of Shelley, Keats, and Hunt reflect the social nature of Cockney poetry and at the same time evoke the emphasis on the perceiving subject characterizing the poetics of Romanticism. Written in 1818, Shelley's "To the Nile," Keats's "To the Nile," and Hunt's "The Nile" reveal the passionate interest in Egypt dominating British cultural life in the early nineteenth century. The common subject of the sonnet contest was the canvas upon which individual themes emerged. Shelley utilizes the subject figuratively to create an analogy between the course of the river and the workings of the poet's mind, stressing the need for both poetry and the Nile as providers of different, but equally important, types of sustenance; Keats explores the paradoxical nature of the riverscape which combines fertility and barrenness, resolving the tension by exercising his doctrine of "negative capability"; and Hunt dwells on the decline of the great civilization associated with the Nile to convey an implied critique of political repression, conjoining poetics and rhetoric to inspire hope for social and political change. Despite differences in theme, the three sonnets share an important feature: they epitomize the individual poetics of their writers. The scope of the present paper is not restricted to comparison and contrast. An eclectic research methodology is adopted to gain a thorough insight into the differing treatments of the subject. The poems are considered within the context of the sonnet as a genre in order to show how the thematic concerns take shape and develop through the formal and rhetorical parts associated with the sonnet. A consideration of the history of the exploration of Africa's interior is necessary to understand the Nile's physiography as described in the sonnets. In addition to examining the ways in which textual tensions are resolved, the sonnets are analyzed in light of the poetics informing them. Since Hunt's sonnet has an intended effect relevant to its audience, the sound devices/patterns and the rhetorical modes enhancing the poem's message are also examined.

\section{Key words:}

The Nile Sonnets - Romantic poetics - Shelley - Keats - Hunt

\section{Introduction:}

Usually considered as a self-consciously defined group of writers and intellectuals who gathered round Leigh Hunt and shared political as well 
as literary views, Romantic poets of the second generation, which included Shelley, Byron, Keats, Hunt, Smith, and Hazlitt, often engaged in writing poetry as a group activity through participation in themed sonnet-writing contests. Some of their most famous poems like Shelley's "Ozymandias" and Horace Smith's "On a Stupendous Leg of Granite" emerged from such contests in which they challenged each other to write a sonnet on a particular topic in a quarter of an hour. Shelley's "To the Nile," Keats's "To the Nile," and Hunt's "The Nile" were their contributions to one of these poetic competitions. The three poets gathered at Hunt's Hampstead cottage on 4 February 1818 and wrote each a sonnet on the Nile River. As the headnote to Keats's Nile sonnet in The Poems of John Keats indicates, Keats and Shelley finished within the set period of fifteen minutes. Shelley's sonnet was published in 1876, Hunt's in 1818, and Keats's in 1838 (307-08).

The idea of writing poems about the Nile might have originated from the passionate interest in Egypt which became a prominent feature of British cultural life in the early decades of the nineteenth century. In addition to the fact that Egypt appealed to the Romantic interest in the remote and exotic, excitement about Egypt in the early nineteenth century, as Sophie Thomas points out in "Displaying Egypt," was kindled by Napoleon's military expedition of 1798-1801 as well as by the activities of the Italian excavator of Egyptian archaeological sites Giovanni Battista Belzoni in Egypt in the years 1815-1819 (6-7). The resounding victory of the British navy over the French fleet at the Battle of the Nile in 1798 and the archaeological discoveries in Egypt gave rise to an obsession with ancient Egypt which found expression not only in the work of artists and writers but also in many aspects of popular, visual culture. Thomas explores manifestations of this enchantment with ancient Egypt: the British victory at the Battle of the Nile inspired a panorama representing the event and provoked a patriotic vogue for decorative obelisks and sphinxes; the efforts of scholars and artists accompanying Napoleon's Egyptian campaign aroused an interest in the adoption of an Egyptian style in architecture, interior design, and theatre sets in Britain; and the exhibitions displaying Belzoni's collections and drawings of Egyptian antiquities captured the public imagination (7-10).

Artistic representations of Egypt in the early nineteenth century gave prominence to ancient Egypt by focusing on Egyptian antiquities and monuments as well as on sites of archaeological interest and scenes of Cairo with the Nile and the Pyramids. This foregrounding of images of ancient Egypt had a substantial impact on the Romantic poets who represented the Nile in their sonnets as a river associated mainly with the 
ancient Egyptian civilization. In Hunt's "The Nile," the river "flows through old hush'd Ægypt," outliving the great civilization built around it by "the shepherd bands" (line 1,5), and in Shelley's "To the Nile," its waters run across "Egypt's land of Memory" (9). Keats's "To the Nile" describes the river as "Chief of the pyramid," stressing its connection with "swart nations since the world began" $(2,5)$.

\section{Geographic and Mental Spaces "in strange embraces blend":}

The Nile Sonnets incorporate descriptions of the river's physical geography which mingle contemporary scientific knowledge with classical and mythological accounts of the sources of the Nile. The Romantic poets' delineations of the Nile River are not based on direct experience. As Hala Darwish has observed, none of the major or minor English Romantic poets had ever been to Egypt (273).

The Nile has two main tributaries: the White Nile, which flows from Lake Victoria in Uganda, and the Blue Nile, which originates in Ethiopia. The two tributaries join at Khartoum and the northern section of the river passes through Sudan to Egypt, forming a large delta before emptying into the sea. Explorations for the sources of the Nile, which remained a challenging mystery for two or three millennia, began in the ancient world. The ancient Greek historian Herodotus, who visited Egypt in 457 $\mathrm{BC}$, travelled up the Nile and reached the waterfalls near present-day Aswan but turned back because the cataract was an impenetrable barrier for boat voyage. It was not until the seventeenth century that exploration of the Nile began in earnest. According to the Encyclopedia Britannica, an expedition led by Pedro Páez (1564-1622), a Spanish Jesuit priest, was successful in locating the source for the Blue Nile in 1618 ("Nile River").

In Slavery and the Romantic Imagination (2002), Debbie Lee sheds light on the Western attempts at "Mapping Interiors" of the African continent between the eighteenth and the nineteenth centuries. The African Association, formed in London in 1788 to sponsor African exploration, sent a series of travelers to follow James Bruce who had independently explored the Nile between 1760 and 1770s (143). Bruce recorded his journeys in a book titled Travels to Discover the Source of the Nile, issued in 1790, which includes an account of Ethiopian history, culture, and geography. Bruce was not alone and his book was not the only source of information with respect to Africa's geography. Lee notes that between 1790 and 1820 over fifty travel books bearing titles of Africa's interior appeared in Britain alone. In these books, travelers to Africa recorded stories and accounts of their journeys and also provided drawings, tables, catalogs as well as natural history descriptions to satisfy scientifically-minded readers (143). Therefore, the remote continent was 
placed within Europeans' reach via the information brought back by African travelers and explorers. Thus, in their descriptions of the Nile's source and trajectory, the Romantic poets could rely on geographical information provided by these reports.

Despite explorations and attempts to strip African cartography of false geography, large parts of Africa's interior remained unknown in the early decades of the nineteenth century. In the course of his analysis of Shelley's poem "The Witch of Atlas," Nahoko Alvey states that in Shelley's day the interior of Africa south of the Atlas Mountains remained as obscure as it had been in the days of Herodotus (156). The mystery of the Nile's source was resolved long after the Nile Sonnets had been composed when the British explorer John Hanning Speke (1827-1864) reached Lake Victoria, from which the White Nile issues, in 1858.

Intended to serve science and empire, exploration and discovery were followed by representation which took the form of maps and narrative accounts of exploration before giving way to literary representations of newly discovered interiors. Poets made use of the knowledge provided by maps and explorers' narratives to reconstruct geographical space and remote areas from a distance. At the hands of the British Romantics, probing Africa's interiors was employed as a metaphor for the exploration of the workings of the mind and the process of poetic inspiration and creation. Thus, in their representations, poets brought together geographical as well as mental and psychological landscapes.

After exploration, sub-Saharan Africa "was to become one of the places in which literary Romanticism staged its journeys into the self," wrote Fulford, Lee, and Kitson in Literature, Science and Exploration in the Romantic Era (90). Exploration of Africa and the travel narratives offered by the explorers had a substantial impact on the forms and figures developed by the poets as they provided the Romantic poets with subjects, settings, and metaphorical constructs to explore mental space and to speak of the mind and the poetic imagination. Bringing the unknown and exotic within reach, African travel narratives were foundational texts to the Romantic poets because "they gave the poets not only a new subject-matter, but contributed a new poetic: they stimulated them to convert material journeys into mental travel, to turn the world outside in" (Fulford, Lee, and Kitson 98). This fusion of Africa's interior with human interiority characterizes the Nile Sonnets of Shelley, Keats, and Hunt where geographical spaces came to symbolize imaginative ones. Pinpointing this significant aspect of the three poems, Debbie Lee states that the Nile Sonnets show "the well-traveled analogy between Africa's interior and the interiority of the British psyche." The three poets, 
Lee adds, "expand African mysteries to make them stand for the British imagination, especially in their barrenness and fruitfulness, lack and plenty" (158-59).

In spite of the above-mentioned references to the inwardness and mental exploration characterizing the Nile Sonnets, no single study has scrutinized this definitive feature of the poems. The current study sets out to fill this knowledge gap by closely examining the Romantic poets' attempts to chart their mental/imaginative interiors as they describe their imaginative expeditions into Africa's interior.

\section{"[R]ivers...imitate mind": Shellev's "To the Nile"}

Shelley's description of the physiography of the Nile in his "To the Nile" juxtaposes contemporary scientific knowledge with classical/fictional accounts of the Nile sources. Apart from the deficiency of geographical information respecting the two main tributaries of the Nile at the time the sonnet was composed, the juxtaposition marries the actual and literal with the fictional and metaphorical, thus pinpointing the poetic reconstruction of geographical landscape at work in the poem. The course of the Nile will be seen in its reality as well as through imaginative eyes.

Shelley locates the two sources of the Nile in the mountains in Ethiopian highlands and the Atlas Mountains in northwestern Africa, a hypothesis based on the false geography for which the classical Greek geographer Herodotus was responsible. Herodotus "mistakenly located the source of the Nile in the West" (Alvey 167). Shelley's reference to Herodotus in his Defence of Poetry as one of the "great historians" who "were [also] poets," as they filled "all the interstices of their subjects with living images," shows his familiarity with and admiration for the classical historian and geographer.

As delineated in Shelley's Nile sonnet, the Nile receives its water from the heavy monsoonal rainfalls within Ethiopian highlands and the melting snow on Atlas Mountains:

Month after month the gathered rains descend

Drenching yon secret Aethiopian dells,

And from the desert's ice-girt pinnacles

Where Frost and Heat in strange embraces blend

On Atlas, fields of moist snow half depend. (1-5)

Shelley's poem is constructed around a metaphor. This is not unusual in the sonnet as a verse form; the sonnet form can make use of metaphor to build its structure. In The Art of Poetry (2001), Shira Wolosky explains that in the compact territory of the sonnet "metaphorical construction can provide both a method of organization and an avenue of development, as 
relationships multiply through the course of the poem" (46). The mountainous landscape described at the beginning of Shelley's Nile sonnet suggests that the poet is exploring visitations of poetic inspiration and the workings of the poet's mind in metaphorical terms. Mountains are traditional images of places of spiritual communion, enlightenment, and revelation. They are the meeting point between earth and heaven in the same way as poetry brings together the human and the divine. "Poetry is indeed something divine," asserts Shelley in the Defence; poetry, Shelley adds, "redeems from decay the visitations of the divinity in man" $(76,81)$. Mountains and rivers are two archetypal Romantic emblems of revelation and creation respectively. Paige Tovey observes that the Romantic tradition manifests a reverence for mountains, which are often considered alongside companion rivers and valleys. Wordsworth and Shelley approach mountains "as symbols of the imagination and of revelation in differing senses" (157).

Shelley uses capitalization to highlight certain features of the landscape he is representing. In the mountainous landscape from which the Nile issues "Frost" and "Heat" are intermingled. The capitalized words are given prominence and the unusual punctuation invites the reader to ponder over a more imaginative interpretation for the contradictory terms other than their literal reference to the contrasting and extreme climate conditions that actually characterize highlands where ridges and summits may be snow-capped while deserts with high temperature lie at the base of the mountains. In reality, extremes are the norm in mountain climate, which is also characterized by large variations in short time spans. Mountains blend extremes, and poetry, as represented by Shelley in his Defence, conjoins opposites: "it marries exultation and horror, grief and pleasure, eternity and change; it subdues to union under its light yoke all irreconcilable things" (82). The analogy between the sources of the river and the wellsprings of poetry from Shelley's perspective is also worth noting. The river starts high up in the mountains; it flows from "secret" (that is, unearthly and unfathomable) rivulets in mountain tops. In the Defence, Shelley uses imagery denoting elevation and ascent to describe the heavenly sources whence poetry originates: poetry "ascend[s] to bring light and fire from those eternal regions where the owl-winged faculty of calculations dare not ever soar" (77). A natural behavior of flowing water is to move from high to low. Similarly, poetic inspiration comes from a lofty, elevated fountainhead.

The parallel between the movement of the river from its source to its mouth and the processes of the poet's mind is further developed in Shelley's Nile sonnet: 
Girt there with blasts and meteors Tempest dwells

By Nile's aëreal urn, with rapid spells

Urging those waters to their mighty end. (6-8)

Strong winds help bring down water from the river's source and urge the flowing waters towards the river's mouth. The river's headwaters could be seen as a metaphor for the flow of energy in the poet's mind in moments of creation. The forces of nature acting upon the river at its source (which include "blasts," "meteors," and "Tempest") are swift, sudden, unexpected, and unanticipated. They are reminiscent of the "evanescent visitations" of poetry which Shelley describes in the Defence as "always arising unforeseen and departing unbidden." Those "happiest moments" are described in terms of the effect of wind on a water body: "It is as it were the interpenetration of a diviner nature through our own; but its footsteps are like those of a wind over the sea" (Shelley, Defence 79-80).

The riverscape described by Shelley in the lines quoted above features varied forms of sudden blows of air as well as meteors which produce bright light. The image of wind acting as an agent and producing brightness is again utilized by Shelley in the Defence to metaphorically describe the initial moments of the creative process: "for the mind in creation is as a fading coal, which some invisible influence, like an inconstant wind, awakens to transitory brightness" (77). Finally, the "mighty end" blurs the distinction between the literal and the figurative, referring, at one level, to the larger body of water into which the river empties, and symbolizing, at another level, the work of art which is the ultimate end of poetic inspiration and imaginative creation.

The idea of the analogy between the flow of water and the movement of mind and/or life was not alien to Shelley's mindset, nor was it unfamiliar in the Romantic tradition. Shelley compares rivers to mind in a letter of July 17, 1816, in which he tells Thomas Love Peacock of his desire to tour Europe by following the course of "great rivers." Describing rivers, Shelley adds: "rivers are not like roads, the work of the hands of man; they imitate mind, which wanders at will over pathless deserts, and flows through nature's loveliest recesses, which are inaccessible to anything besides" (qtd. in Tovey 188). The image of the river is also a central image in Romantic-era poetry. Romanticism saw a profusion of sonnets addressed to rivers; examples include William Lisle Bowles' numerous river sonnets, Coleridge's "Sonnet to the River Otter," and Wordsworth's sequence The River Duddon. The Romantic poets adopted the river as a symbol. "For the Romantics," Duncan Wu explains, "the river is a powerful emblem of the workings of the mind- springs are associated with inspiration, waterfalls (cataracts) with the abyss, 
meanders with recollection as the mind rounds on itself." The river is "simultaneously an emblem of flux and of stability," and also "a metaphor for life" in Romantic poetry $(\mathrm{Wu})$. Thus, the association between rivers and mind is a conventional Romantic motif revisited in Shelley's Nile sonnet.

The first eight lines of Shelley's Nile sonnet introduce and develop the analogy between the course of the river and the operations of the poetic mind. They are held together by the standard enveloping rhyme scheme of the octave in a Petrarchan sonnet (that is, $\mathrm{a} b \mathrm{~b}$ a a b b a). The octave in a Petrarchan sonnet is followed by a sestet which typically begins with a volta - that is, a turn in thought or new direction which the sonnet takes in its final six lines. The volta, which occurs in the ninth line of Shelley's sonnet, signals a shift in emphasis and suggests self-reflection. According to tradition, a sestet falls into two parts: the first tercet begins the resolution and the final tercet presents the conclusion. Shelley's poem violates this rhetorical development and divides the sestet into a quatrain and a concluding couplet (which is typical of the Shakespearean sonnet) where a further turn occurs.

The opening line of the sestet suggests the flux and stability characterizing the flow of the Nile waters across Egypt:

O'er Egypt's land of Memory floods are level

And they are thine, O Nile-and well thou knowest

That soul-sustaining airs and blasts of evil

And fruits and poisons spring where'er thou flowest. (9-12)

Shelley turns suddenly from thoughts of the regular returns of the Nile flooding to apostrophize the Nile River. An apostrophe is a rhetorical figure that expresses emotional intensity; the lines that follow actually reveal that the poet is experiencing a sudden emotional impetus. Shelley's apostrophe focuses on the opposite possibilities for life and death, creation and destruction, famine and fertility inherent in the Nile flooding. The Nile waters made intensive cultivation possible along its banks. However, excessive flooding was another facet to the behavior of the Nile water, causing destruction and loss and leading to the fatal outbreak of diseases. While winds help bring about rainfall which causes the river to rise, storm surge contributes to the occurrence of the destructive/deadly flooding. Thus, the movement of water blends opposites, epitomized by the antithetical "fruits" and "poisons."

Again, the mental/psychological map of poetic inspiration and imaginative creation superimposes itself upon the real topographical map of the river. An expansion of significance is encouraged by the qualities Shelley attributes to the wind concomitant with the periodic flooding of 
the Nile: productive winds are "soul-sustaining," while extreme winds inducing the destructive flooding are associated with "evil." This level of abstraction, alongside the metaphorical interpretation of the wind in the sonnet's octave, reinforces the view that those antithetical winds are simultaneously emblems of the inspired moments and of the moments of despair and isolation Shelley experienced when society rejected him for his rebellion against authority. Like the Nile flooding, the poetic vocation as embraced and practiced by Shelley involves both "fruits," symbolizing artistic creations which partake of the beautiful and eternal, and "poisons," which are emblematic of the venomous attacks launched against poets with idealist and radical views like Shelley.

In the introduction to his poems in The Norton Anthology, Shelley is characterized as "an extreme heretic and nonconformist in all his life and thought" (Abrams et al. 504). Shelley embraced radical views, including atheism, even at the risk of being unpopular and ridiculed. He was a bitter critic of social injustice and dreamed of changing the world through poetry. His scorn of orthodoxy was reflected in his writings and in the way he lived. He was expelled from Oxford University during his first year for writing a pamphlet defending atheism, an event which scandalized his family and alienated him from his father for the rest of his life. Because of his radical ideas, Shelley almost lacked an audience and could not publish some of his poems. In 1814, Shelley was ostracized for his elopement with Mary Wollstonecraft Godwin. He was considered not only an atheist but also a revolutionary and immoralist. Due to the criticism that his radical views and personal behavior drew from his contemporaries, Shelley "saw himself in the role of an alien and outcast, scorned and rejected by the mankind to whose welfare he had dedicated his powers and his life" (Abrams et al. 506).

Utilizing the effect of an epigrammatic turn which is characteristic of a Shakespearean sonnet's concluding couplet, Shelley's sonnet concludes with a couplet structure:

Beware, O Man-for knowledge must to thee,

Like the great flood to Egypt, ever be. (13-14)

Apostrophizing humanity at large, Shelley voices an impassioned outcry in defence of the importance and indispensability of poetry. The concluding couplet is the poem's ultimate feat of subtlety and indirection. Shelley refers to poetry by way of metonymy: "knowledge" signifies poetry. The change of names is justified by the fact that poetry is closely associated with knowledge in Shelley's poetics. The interconnection between poetry and knowledge is established and reasserted in his Defence of Poetry. One major function of the "poetical faculty" according to Shelley is that "it creates new materials of knowledge, and power, and 
pleasure" (Shelley, Defence 75). Reaffirming the association between poetry and knowledge, Shelley writes:

Poetry is indeed something divine. It is at once the center and circumference of knowledge; it is that which comprehends all science, and that to which all science must be referred. (Defence 76)

According to Shelley, the poets have access to a special kind of knowledge; they are authors to others of universal and eternal truths pertaining to human nature. "A poem is the very image of life expressed in its eternal truth," declares Shelley in the Defence. A poem is "universal, and contains within itself the germ of a relation to whatever motives or actions have place in the possible varieties of human nature," he adds $(27,28)$. A poet is endowed with a special insight into life that he imparts through poetry. He "not only beholds intensely the present as it is, and discovers those laws according to which present things ought to be ordered, but he beholds the future in the present" (Shelley, Defence 20). For Shelley, poetry effects the moral development of man and offers wisdom mingled with delight. It "strengthens the [imaginative] faculty which is the organ of the moral nature of man" (Defence 34-35). Thus, the utility of poetry is unquestionable as it is an indispensable source of spiritual, moral, and mental sustenance. The knowledge provided by the calculating faculty enables man to gain control over the external world, but the poetic faculty provides a superior type of knowledge which nourishes the inner world of man.

The primary water source in Egypt, the Nile River is the lifeline of civilization and the provider of sustenance and nourishment. Similarly, poetry is a supplier of a distinct sort of replenishment that is necessary to the superior portions of our being.

\section{"[W]hen man is capable of being in uncertainties": Keats's "To the Nile"}

The two sonnets on the Nile composed by Shelley and Keats epitomize the differences between their poetical characters and exemplify the dissimilar ways in which the two contemporaries and friends practiced their art. Both poems are inward oriented; they both indulge in a kind of analytical reasoning. The concern with the poet's imaginative faculty is discernible in both sonnets. But while Shelley's poem expresses a coherent poetic principle, Keats's poem evades the articulation of a doctrine or singular opinion. In Shelley's "To the Nile," all the elements of the riverscape are reworked poetically in order to consolidate Shelley's pronouncement on the workings of the poet's mind and the inception, 
nature, and final product of the inspired moment. In contrast to Shelley's sonnet, Keats's "To the Nile" shows the poet's unwillingness to synthesize an individual proposition; it is expressive of Keats's aptitude to tolerate irresolution and to resist imprisonment in fixed opinions. This does not mean that the poem is an exercise in indecisiveness; it is rather emblematic of poetic objectivity - that is, openness to the appreciation of beauty which constitutes a special kind of truth for Keats that is more important than the quest for or the enforcement of objective facts.

On the basis of this question of objectivity, David Masson makes a comparison between Shelley and Keats in the article titled "The Life and Poetry of Keats," published in the November 1860 issue of the Macmillan's Magazine. Masson differentiates between "two recognized orders of poets" which he calls "subjective" and "objective." To the class of subjective poets, "Shelley himself belonged." The "peculiarity" of poets in this class is that "their poems are vehicles for certain fixed ideas lying in the mind of their authors, outbursts of their personal character, impersonation under shifting guises of their wishes, feelings and beliefs." On the other hand, poets classified by Masson as objective "simply fashion their creations by a kind of inventive craft working amid materials supplied by sense, memory, and reading, without the distinct infusion of any element of personal opinion." Masson concludes that Keats "belongs to this [latter] order" of objective poets along with Chaucer, Shakespeare, and Scott (373). In this respect, Keats and Shelley embraced opposite tendencies which were reflected in the theory and practice of their art. This claim could also be evidenced by the fact that while Shelley articulated a coherent vision of his poetic vocation in his Defence of Poetry, Keats only expressed insights into the workings of his art in some of his personal correspondence but he had no system of philosophy. Unlike Shelley "whose life was a shrill...in behalf of certain principles," Keats had "no fixed principles" (Masson 373).

With the exception of two and a half lines at the beginning of the sestet, Keats's "To the Nile," which is cast in the Petrarchan form, constitutes one sustained apostrophe to the Nile River. As he starts his imaginative visualization and representation of the Nile, Keats becomes entangled in a web of paradoxical qualities that characterize this river. In fact, the sonnet's octave seems to be an embodiment of Keats's preoccupation with paradox and the contradictions of experience. The introduction to Keats's poems in The Norton Anthology considers "Keats's characteristic presentation of all experience as a tangle of inseparable but irreconcilable opposites" to be a distinctive quality of his poetry (635).

Addressing the Nile at the beginning of his sonnet, Keats says:

Son of the old moon-mountains African! 
Chief of the pyramid and crocodile!

We call thee fruitful, and, that very while,

A desert fills our seeing's inward span. (1-4)

As the first note to the sonnet in The Poems of John Keats clarifies, the mountains at the source of the Nile River "were sometimes known as the Mountains of the Moon" (308). Keats traces the path of the water's journey from its source up high in the mountains to the sea. As depicted by Keats, the Nile combines opposites. It is sustained by feeder rivers flowing from mountain sources and at the same time it is a sustainer of life in the Nile valley, providing food, water, and transportation since the time of the ancient Egyptians, who transported huge blocks of stones used for building the pyramids along the river in barges to the pyramid construction sites. The Nile also blends fruitfulness and barrenness: the Nile's annual flooding makes Egypt fruitful, but its course flows through the desert.

In addition to the focus on contrasts, Keats's representation of the Nile in the sonnet's first quatrain not only reproduces stereotypical images of Africa, which were beginning to emerge with the rise of interest in the continent, but also stresses the location of the river in a region that occupies the margins of the world by virtue of being far away from and outside the European center. The Nile's Africanness is foregrounded and the association of Africa with wildlife and of Egypt with the ancient Egyptian civilization is asserted through the reference to the "pyramid" and "crocodile."

The opposition between fruitfulness and barrenness reappears in the second quatrain which also introduces the question of primitiveness by demonstrating the Nile's connection with dark/black nations living at an early stage of human development. Still apostrophizing the Nile, Keats poses two questions debating whether or not to consider the river fruitful despite the vision of vast desert that fills the poet's imagination as he reconstructs its course with the help of his mind's eye:

Nurse of swart nations since the world began,

Art thou so fruitful? Or dost thou beguile

Such men to honour thee, who, worn with toil,

Rest for a space 'twixt Cairo and Decan? (5-8)

The Decan plateau is located in India. As the note to the line shows, on their way to India the Englishmen landed at Alexandria and sailed up the Nile River before traveling across the desert to Suez and the Red Sea (Keats, The Poems 308).

Keats's representation of the Nile in the sonnet's octave shows that he adopts a stance of dominance and constructs the River as an other onto 
which he projects features that threaten his identity as a poet. In PostColonial Studies, the "other" is defined as "anyone who is separate from one's self." The existence of others plays a key role in "locating one's own place in the world" (Ashcroft et al. 154). The process of othering comprises a geographical dimension and is based on a hierarchy of civilization. As Jean-François Staszak puts it, "We, here, are the self; they, there, are the Other." Otherness can be essentially geographical when we consider those who are far away as radically different to the point of being others (3).

Othering can be described as the articulation of difference conventionally within the human species. However, Keats's Nile sonnet presents an encounter with a non-human natural entity (i.e. the Nile River) which is represented as an other and subjected to stereotyping and projection. Othering was one of the discursive strategies used by imperialist culture to justify the domination of newly discovered regions. Although Keats is not expressing manifest imperial attitudes, he seems to be influenced by stereotypical depictions of the African continent that were threaded in the narrative accounts of African exploration as well as in cultural discourses that paved the way for the great age of empire which began around 1880. A stereotype is "an arrested, fixated form of representation," and stereotyping is a "limited form of otherness" (Bhabha 77-78).

In Keats's sonnet, the Nile River is first personified as "Son," "Chief," and "Nurse," and then constructed as an other; the aim is not to validate imperial rhetoric but to attempt a coming to terms with vocational concerns. Relevant to Keats's treatment of the Nile is the view of the other as the locus of qualities that threaten our sense of who we are. Janice Allan explains that "the other is not, in any simple way, the direct opposite of the self;" it is best thought of as "a site or location upon which we project all the qualities that we-as individual subjects, social groups or even nations - most fear, or dislike, about ourselves" (164). The alterity of the river allows Keats to confront and handle personal worries relevant to his poetic calling. Keats's paradoxical view of the river is the gateway to this inward encounter. He acknowledges the Nile's significance as a supporter of water that makes Egypt fruitful, as a provider of a habitat for wildlife, and as a major contributor to the establishment of the ancient Egyptian civilization. However, the doubts and uncertainties he expresses emerge from the fact that the Nile winds its way through the desert; it is surrounded by the Eastern and the Western deserts. The fecundity and fruitfulness engendered by the Nile are limited to the flood plain around the river, but it could not redeem the desert beyond itself from barrenness. Thus, the potential of the Nile as a 
producer of fruitfulness and its capacity to enhance prolificacy are not fully realized. The process of othering the Nile allows Keats to project upon the river his fear of the inability to fulfill his poetic ambitions and to fully realize the potential for a richly productive life he anticipated for himself as a writer.

Keats gave expression to these vocational concerns and apprehensions in his sonnet "When I have fears that I may cease to be," written between 22-31 January 1818, that is, a few days before his Nile sonnet. "When I have fears" reflects Keats's concern with poetic ambition, love, and the passage of time. In the first two quatrains of this sonnet, he reveals his fear that he may not have enough time for the ripening and harvesting of his poetic gifts. Using imagery of the harvest, he shows that his imagination is fertile and his mind is teeming with ideas:

When I have fears that I may cease to be

Before my pen has gleaned my teeming brain,

Before high-pilèd books, in character,

Hold like rich garners the full ripened grain;

When I behold, upon the night's starred face,

Huge cloudy symbols of a high romance,

And think that I may never live to trace

Their shadows with the magic hand of chance; (1-8)

Keats is fearful of early death as it would preclude him from fulfilling his poetic aspirations. He worries about dying before collecting his thoughts and committing them to writing. This obsession with premature death haunted Keats throughout his brief life. The introduction to his poems in The Norton Anthology states that "even while his health was good, Keats felt a foreboding of early death, and applied himself to his art with a desperate urgency" (634). The circumstances of the poet's life reinforced these fears: Keats's father had died when Keats was 8, and his mother died when he was 14 . The early deaths of his parents and the shadow of tuberculosis, which killed his mother and his brother, may account for the presence of this early fear. Therefore, it can be argued that Keats transfers his own personal doubts onto the river in his Nile sonnet. Calling into question the Nile's fruitfulness reflects the uncertainty that plagued Keats as to whether he would be able to develop creativeness and poetic productivity to the full. The inwardness that characterizes Keats's poetry in general substantiates this metaphorical reading of the poet's representation of the river. 
The structure of Keats's Nile sonnet is in line with the Petrarchan form; a volta occurs in the ninth line and a new direction of thought is developed in the sestet. Thus begins the sestet:

Oh, may dark fancies err! They surely do.

' $\mathrm{T}$ is ignorance that makes a barren waste

Of all beyond itself.

Keats becomes aware of the fact that the way he thought of the Nile in the octave was marked by submission to analytical reasoning, which divested the river of its charms, and he has no hesitation in rejecting this unpoetic mode of thought. Intuitive appreciation of beauty and the pleasures stemming from the aesthetic experience were restrained by the attempt to rationalize and resolve the paradoxes inherent in the world. Changing his perspective, Keats casts off consecutive reasoning, which clips the wings of poetry and renders lifeless the world that is full of loveliness, and prefers to rely on imagination. According to Keats, unrestrained poetic imagination perceives beauty in the world, whereas obsession with facts and the determination to arrive at full knowledge and resolve all tensions result in a failure to see beauty in the object of contemplation. The beauty that is perceived by the imagination is also truth: "What the imagination seizes as Beauty must be truth — whether it existed before or not," asserts Keats in a letter to Benjamin Bailey, dated 22 November 1817 (Keats, Letters 37). But ultimate reality is to be found when the poet's imagination works untrammeled; therefore, Keats prefers to get beyond the analytical mind and mount on the wings of imagination. In the same letter to Bailey, the poet differentiates between the two modes of perception:

The Imagination may be compared to Adam's dream-he awoke and found it truth. I am the more zealous in this affair, because I have never yet been able to perceive how anything can be known for truth by consequitive [sic] reasoning - and yet it must be-Can it be that even the greatest Philosopher ever arrived at his goal without putting aside numerous objections-However it may be, $\mathrm{O}$ for a life of Sensations rather than of Thoughts! (Keats, Letters 37)

Keats's standpoint in this regard is consistent with the poetics of the Romantic Movement. The great Romantics "trusted not in logic but in insight, not in the analytical reason but in the delighted, inspired soul which in its full nature transcends both the mind and the emotions" (Bowra 22). In the concluding section of his Nile sonnet Keats sees the river through the eyes of his passive imagination which enables the artist 
to transcend the imperfections of the world and opens the way to perceive beauty and truth.

Conventionally, the sestet in a Petrarchan sonnet comprises two tercets, the first begins the resolution to the problem or proposition presented in the octave and the second provides the conclusion. Keats hastens to unveil the shift in the way he sees the Nile a half a line earlier. Resuming his apostrophe to the river, the poet says:

Thou dost bedew

Green rushes like our rivers, and dost taste

The pleasant sunrise. Green isles hast thou too,

And to the sea as happily dost haste. (11-14)

Keats is no longer preoccupied with the attempt to reconcile opposites and resolve contradictions. The contraries of barrenness and fruitfulness and the quest for satisfactory answers to the questions that arose in his mind while visualizing the river cease to trouble him. Putting aside all objections and giving free play to his intuitive imagination, the poet is able to see the Nile in a different light as having beauty, charm, and splendor. Like the rivers that flow through the English countryside, the Nile has lush greenery along its banks, its waters beautifully reflect sunlight, and it flows out happily to the sea. Intellectual analysis has given way to imaginative intensity through which a poet can achieve excellence in art. In a letter to his brothers George and Tom, dated 21, 27 December 1817, Keats wrote: "the excellence of every Art is its intensity, capable of making all disagreeables evaporate, from their being in close relationship with Beauty \&Truth" (Keats, Letters 42). Thus, with the help of imagination as an instrument of intuitive insight the beauty of the river is perceived and affirmed as truth, and all uncertainties and doubts evaporate.

The way in which Keats concludes his Nile sonnet conforms with his doctrine of "negative capability" — a quality believed by Keats to be possessed by men of great genius. The above-mentioned letter to his brothers George and Tom provides insight into his notion of "negative capability" which came into being in a conversation with one of his friends. Describing this conversation, Keats wrote:

I had not a dispute but a disquisition with Dilke, on various subjects; several things dovetailed in my mind, \& at once it struck me, what quality went to form a Man of Achievement especially in Literature \& which Shakespeare possessed so enormously - I mean Negative Capability, that is when man is capable of being in uncertainties, Mysteries, doubts, 
without any irritable reaching after fact $\&$ reason- $-"$ Keats, Letters 43)

By "negative capability" Keats means the willingness to remain in doubt, embrace uncertainty, live with mystery, and be content with half knowledge. Central to literary achievement, this power entails a heightened receptivity and imaginative openness to the world without the determination to work everything out or to find definitive answers. In his article "The Life and Poetry of Keats," David Masson states that Keats recognizes "negative capability" as "the quality that forms men for great literary achievement." This quality is defined by Masson as: "a power of remaining, and, as it were, luxuriously lolling, in doubts, mysteries, and half-solutions, toying with them, and tossing them, in all their complexity, into forms of beauty, instead of piercing on narrowly and in pain after Truth absolute and inaccessible" (374). In his essay on Keats in Prefaces to Criticism (1959), Walter Jackson Bate explains the way in which the mind of a poet possessing the quality of "negative capability" operates:

In a state of intense imaginative gusto, the nature and "identity" of an object is grasped so vividly that only those associations or qualities that are strictly relevant to its central significance appear; the irrelevant or discordant aspects (the "disagreeables") "evaporate"; and the meaning and character of the object (its "Truth") is expressed with so vital a grace that it is also seen as "Beauty". (147)

In Keats's Nile sonnet we see "negative capability" in operation: the poet disregards the need for rational explanations and thrice uses emphatic "do" in its archaic form "dost" to foreground and reassert the beauties of the Nile in the poem's sestet; qualities pertaining to the central significance of the river are caught and relished and the sense of beauty overcomes other considerations. To conclude, Keats has written a poem in keeping with his aesthetic commitment to "negative capability."

\section{Poetry "seeks the deepest impressions": Hunt's "The Nile"}

Recounting the story of the fifteen-minute poetry contest which produced the Nile sonnets, Walter Jackson Bate notes that while Shelley and Keats finished their sonnets in time, Hunt kept working at his until two o'clock in the morning, and "turned out one of the best sonnets he ever wrote" (John Keats (1963), 300). Leigh Hunt's "The Nile," also known as "A Thought of the Nile," displays virtuosity in terms of the congruity between the political implications it involves and the rhetorical and sound devices utilized by the poet to reinforce the poem's intended effect. 
A Petrarchan sonnet in which the octave and the sestet are cast into two convoluted sentences, Hunt's "The Nile" reveals his concern with political reform. The poem's political significance has been noted and addressed by Hala Darwish in a paper entitled "Ancient Egypt as Metaphor" (2009) which links Hunt's "The Nile" with Shelley's "Ozymandias," and Horace Smith's "On a Stupendous Leg of Granite" on the grounds that in the three sonnets the Romantic poets "considered the ephemeral nature of political power to imply a critique of their rulers" (265). However, the present research paper investigates the relationship between the poem's politics and Hunt's poetics of "cheerfulness." The paper also discusses silence as a predominant motif in the poem; a hushed setting is depicted and a sense of stillness pervades the sonnet until the final tercet which breaks the silence by introducing a verb pertaining to sound. Despite this preoccupation with suppression of voice, textual analysis shows that Hunt's sonnet voices a protest against enforced silence. Written at a time marked by repression of traditional liberties and authored by a reformer who was actually imprisoned for two years (18131815) for criticizing political authority, Hunt's Nile sonnet should be considered within its historical context.

A turbulent period in political and economic history served as a background to the Romantic Movement (1798-1832), which not only reflected and responded to the dramatic changes taking place in the Western world as a result of wars and revolutions but also flowered as a movement of protest stressing the need for personal freedom and radical reform. Some of these drastic changes had already started in the late eighteenth century. One major change which rocked the social and economic structure of the nation was the evolution of England from a primarily agricultural society to a modern industrial nation. Romanticism also saw the aftermath of the American Revolution (1775-83), which resulted in the loss of one of the most profitable regions of the British Empire, and the more radical French Revolution. Erupting in 1789, the French Revolution stimulated radical social thinking but eventually followed a grim and violent course and culminated in a dictatorship under Napoleon. The French Revolution was followed by the Revolutionary and Napoleonic Wars (1792-1815), which comprise a twenty-three-year period of recurrent military conflicts between France and coalitions of European states. Britain entered upon war against revolutionary France from 1793 to 1802. British wars with Napoleonic France were renewed in 1803, and hostilities continued until Napoleon's defeat in the Battle of Waterloo in 1815. 
Fear of invasion of Britain by France and the threat to the social order from imported revolutionary ideologies prompted a conservative reaction throughout most levels of the British society and gave rise to the enforcement of repressive measures in order to maintain social and political stability. In the introduction to the Romantic era, The Norton Anthology describes this period in England as "one of harsh repressive measures." Public meetings were prohibited, habeas corpus was suspended, and advocates of political change were charged with treason in time of war. The Anthology points out that the "Napoleonic wars put an end to reform, and to almost all genuine political life in England, for more than three decades" (2).

In 1811, amid war with France, King George III, who suffered periodic bouts of mental illness, was declared incurably insane; his eldest son George, Prince of Wales, became Britain's Regent, or acting ruler. The Regency ended with the death of George III and the coronation of the Prince of Wales as George IV in 1820. Leading an extravagant lifestyle, Prince George was detested by his people and his ministers found his behavior irresponsible. He also thwarted dreams of political reform when he kept the existing conservative Tory government in power instead of giving power to the more liberal Whig party. The introduction to Romanticism in The Language of Literature: British Literature (1997) characterizes Prince George as "a spendthrift with loose personal morals," who had been "a gambling buddy" of the Whig leader Charles Fox. Though he had always favoured the Whigs, he abandoned them when he came to power and sided with the Tories, thus shattering hopes of domestic reform. Anyone who criticized Prince Regent too openly became subject to arrest and imprisonment (479).

The end of the Napoleonic Wars was followed by a period of distress and social unrest in Britain lasting from 1815 to 1820 . The social and economic changes brought about by the continuing process of industrialization coincided with population expansion and a cyclic pattern of relative prosperity and depression. These profound changes gave rise to conflicts between classes with opposing economic interests and unequal political powers like the agriculturalists, who could protect their economic position because they were predominant in Parliament, and the industrialists, who were still demanding a voice in Parliament. Such conflicts exacerbated the need for political reform. Furthermore, the working class bore the main brunt of the post-war difficulties. As a result of their poor economic conditions and their political disability - as they were unrepresented in Parliament - they resorted to riots and disorders. Instead of addressing the problems leading to their mobilization, the ruling class passed more repressive measures. There were radical riots in 
1816 and 1817. Renewed agitations in 1819 culminated in the event known as the Peterloo Massacre, when soldiers brutally dispersed a large assembly of workers who had gathered to demand the reform of parliamentary representation.

Composed in 1818, Hunt's "The Nile" was written at a time when the government continued to pursue policies of repression as a remedy for the general soreness and increasing agitations for the acquisition of political power. Hunt was a man of varied talents. In addition to the large body of poetry he produced, he was an essayist, a playwright, a reviewer, a literary critic, and an outspoken liberal journalist who confronted oppression with courage. In 1808 , he began with his brother John a very influential weekly periodical known as the Examiner which, according to The Norton Anthology, "ran for fourteen years as the most formidable opponent of the oppressive Tory government" (729). Hunt was editor of the Examiner from its inception until his departure to Italy in 1821 . He was reform-minded, and his political essays revealed his profound concern with contemporary events. As editor of the Examiner, Hunt led the campaign for parliamentary reform and civil rights for Irish Catholics (Roe 1).

Reform is, by definition, a change for the better. The concern with reform implies dissatisfaction with the present and a desire to actualize a future vision; it also suggests rejection of stasis and silence in favour of motion and voice. The first quatrain of Hunt's Nile sonnet represents, by means of symbols and elaborate comparisons, these binary oppositionsnamely, motion versus stasis, the present versus the future, change versus inertia, and silence versus voice. The typically Romantic comparison between the flow of the river and the movement of the mind introduced at the poem's outset signals the journey into the sphere of thought the poet is going to undertake in the course of the poem:

It flows through old hush'd Ægypt and its sands,

Like some grave mighty thought threading a dream,

And times and things, as in that vision, seem

Keeping along it their eternal stands, -

The flow of the Nile across Egypt's sands is compared to a mental/imaginative process envisioning a dream. This mental process is of magnitude and it is heading towards a better vision of the future. The comparison is further developed: everything around the Nile, and in the vision under consideration, appears to have come to an eternal standstill. The attention-catching long dash is followed by the second quatrain, which enumerates and specifies the "times and things" that came to a halt:

Caves, pillars, pyramids, the shepherd bands 
That roamed through the young world, the glory extreme Of high Sesostris, and that southern beam,

The laughing queen that caught the world's great hands.(5-8)

As Feldman and Robinson point out, the octave in a Petrarchan sonnet can be grouped into two quatrains: the first four lines usually present a proposition, and the next four lines "either restate, qualify, or contrast with them" (5). The dash at the end of the first quatrain is not simply intended to summarize or introduce a catalogue of times and things associated with the Nile which seem to be unaltered by the passage of time; rather, it signals a subtle turn in thought in the next quatrain where the poet provides a succinct outline of the rise and fall of the great civilization built around the Nile.

Civilizations go through a cycle analogous to the stages through which living organisms pass. Stages in this cycle generally include: genesis, growth, senescence, collapse and decay. In Hunt's Nile sonnet these stages are represented by the gradual shift from "Caves" to "pillars," and "pyramids" constructed by the "shepherd bands," who established one of the greatest civilizations of the young world, and then to the glorious achievements epitomized by the "glory extreme" attributed to the ancient Egyptian pharaoh Sesostris. The final stage of decline and decay is depicted via reference to Cleopatra VII - the most famous of the ancient Egyptian queens who captivated two powerful Roman leaders, Julius Caesar and Mark Antony. Cleopatra, who reigned from 51 to 30 BC, was the last ruler of the Ptolemaic Kingdom of Egypt and the last queen of Egypt. After the Roman armies of Octavian (later emperor Augustus) soundly defeated the combined forces of Mark Antony and Cleopatra in 31BC, Egypt fell under Roman domination. This conquest of Egypt marked the end of the ancient Egyptian civilization which was incorporated into the Roman civilization. Unlike the vast majority of the ancient Egyptian queens who enjoyed less fame, the story of Cleopatra VII (born in 70/69 and died 30 BC) was preserved because she had lived in a highly literate age and her actions were recorded as an integral part of Roman history; hence the reference in the last line of the octave could be interpreted as an allusion to the ancient Egyptian queen whose story could not be forgotten.

The decline of the ancient Egyptian civilization evinces the impermanence of political power and the inevitability of change. Reconsidering the octave of Hunt's Nile sonnet in light of this idea, it becomes clear that the stanza which seemingly depicts an atmosphere of inertia and silence is filled with motion and voice. Ceaseless motion is suggested by the continuous flow of the Nile, which outlived the civilization flourishing along its banks, and the ongoing process of 
threading a dream. The statement about the stillness of "times and things" is made less forceful through the use of the verb "seem."

To express firm resistance to the enforcement of silence, the poet makes heavy use of sibilance, especially through the repetition of the hissing sibilant sound "s." Sibilance is defined as a literary device "in which a hissing sound is created within a group of words through the repetition of "s" sounds" (Schlegel). In sibilance, the repeated sibilant consonants can appear anywhere in the words, and in stressed or unstressed syllables. Words with sibilant sounds produce an onomatopoeic effect, and they should be relatively close in a sentence or paragraph. Although it is sometimes argued that only the "s" sound creates true sibilance, the list of sibilants can also include the sounds "sh," "f," soft "th" and also the buzzing sounds "v," "z" and hard "th," as these sounds produce a hiss not that different from the "s" sound (Schlegel). According to the online Encyclopedia Britannica, sibilants produce a hissing sound when pronounced, and, in English, they include the sounds "s," "z," "sh," "ch," "j," and "zh" (as in "pleasure"). Sibilants can be divided into hissing sounds and hushing sounds. Hissing sibilance, produced by sibilants like "s," soft "th," and "x," can be harsh on the ear and might add to the effect of cacophony in a passage. Hushing sibilance is created by the sounds "ch," "sh," "dg" (as in "judge") and "s" as pronounced in "pleasure." Hushing sibilance has a calming and euphonic effect.

The octave in Hunt's Nile sonnet contains very few examples of hushing sibilance in the words "hush'd," "vision," and "shepherd;" as the language of the sonnet is not intended to be soothing or sweet-sounding. However, a riot of hissing and buzzing sibilants creates an atmosphere of aural disturbance in the octave: examples of sibilance can be seen in the words "flows," "sands," "times," "things," "seem," "stands," "Caves," "pillars," "bands," "extreme," and "hands." The name "Sesostris" contains four hissing sibilants all in one word. These numerous examples of hissing sibilance betray an unmistakable sense of agitation. Furthermore, the difficulty of articulating sibilants in close proximity (as in "flows through," "its sands," and "that southern") intensifies the unpleasant auditory effect of sibilance in the stanza. When read aloud, the lines sound harsh, rough, and cacophonous. Through the subtle use of sibilance, Hunt voices his protest against coercive silence by making disturbing noise. Another effect of sibilance is that it links and emphasizes the words that resonate with the poem's major theme (as in "thought threading" which hints at the political implications of the sonnet). Finally, sibilance slows down the reading process so that readers 
can grasp the poem's disquieting message which is intended to ignite the desire for political change.

The sestet is expected to begin with a volta marking the turn of thought from problem to resolution. Hunt breaks the rule and violates the sonnet tradition by delaying the resolution to the second tercet. In the sphere of politics, Hunt was a nonconformist who developed wide reputation for his political essays in the Examiner; through these political essays he attempted to keep alive the hope of social and political change. The way Hunt employs the rhetorical pattern of the Petrarchan sonnet reflects his spirit of defiance and bold resistance to coercion and repression.

The first tercet depicts a bleak situation characterized by suspension of voice and motion:

Then comes a mightier silence, stern and strong,

As of a world left empty of its throng,

And the void weighs on us;.........

In the octave Hunt described the "thought threading a dream" as "mighty;" the comparative form of the same epithet is used to characterize the silence pervading the opening lines of the sestet, thus connecting the voice that is being suppressed to the domain of thoughts dwelling upon visions of a better future. Hunt was preoccupied with thoughts of reform, and the pronoun reference he uses (i.e. "us") to describe the burden of inhabiting an empty world where motion and voice are controlled supports a reading of the above-quoted lines as an implicit reference to his own personal prison experience. Hunt was coerced into silence; he was fined and imprisoned for two years, from 3 February 1813 to 2 February 1815, after publishing an article in the Examiner criticizing the unpopular Prince Regent in very harsh terms. Hunt portrayed Prince George as:

a violator of his word, a libertine over head and ears in debt and disgrace, a despiser of domestic ties, the companion of gamblers and demireps, a man who has just closed half a century without one single claim on the gratitude of his country or the respect of posterity! (qtd. in Roe 3)

The article was part of an ongoing attack on the Prince Regent; Roe describes Hunt's portrayal of Prince George as "a truth universally acknowledged" (3), but publishing it in the Examiner cost Hunt and his brother John five hundred pounds each and put them in prison for two years. Following this incident, Hunt was considered "a martyr for liberty," and was depicted in cartoons as "'A Free Born Englishman,' bound with irons and forcibly silenced" (Roe 3). 
Hissing sibilance "might indicate a more disturbed mental state" ("Sibilance"). In the previously quoted tercet alluding to his prison experience, Hunt uses a mixture of buzzing and hissing sibilance. Examples include the repetitive use of the sibilant "s" in the words "silence" (which has two sibilants), "stern," and "strong;" and the use of the buzzing "z" sound in "comes," and "weighs," which confers a sense of heaviness. Sibilance in these lines reflects the distress befalling the poet as a result of imprisonment. More importantly, hissing sibilance also shows the poet's unyielding insistence on being vociferous in criticizing political oppression.

Impatient to dispel the despondent mood pervading the opening lines of the sestet, Hunt shifts to a more cheerful and hopeful tone before the first tercet comes to an end. The verb "wake" is used metaphorically to suggest that the period of enforced silence and despair could be compared to a short nightmare from which the poet soon awakens. The sonnet's final tercet is imbued with hopefulness and revitalized sense of purpose inspired by the ceaseless flow of the Nile:

And the void weighs on us; and then we wake,

And hear the fruitful stream lapsing along

'Twixt villages, and think how we shall take

Our own calm journey on for human sake. (11-14)

Enjambment causes line 12 to flow through into line 13, imitating the movement of the Nile as it glides across villages in Egypt. The poet's choice of diction inspires a sense of confidence in the power to realize dreams of political reform. The Nile is described as "fruitful," emphasizing the fertility brought about by its flow. The quality of being fruitful (in the sense of the ability to bring about change) can also be applied to the workings of the poet's mind on the grounds that the poem's octave has compared the River's flow to the processes of a mind weaving a future vision. Renewed hope is also conveyed through the poet's use of "villages" in place of the "sands" of the octave.

The emphasis on hearing in the lines cannot be overlooked as sibilance is again utilized to provide vocal metaphors. The hushing sibilance in "villages," "shall," and "journey" imparts a sense of equanimity. But sound persists in the softer consonants of sibilance, such as the "s" sound in "stream," "lapsing," and "sake," which symbolize the continuity of the relentless effort to instill hope and also convey a sense of confidence in the power of words and voice to induce change. Thus, while the poem's syntax expresses resistance to closure, its sound patterns communicate an insistence on breaking the silence imposed by coercive measures. 
Hunt's Nile sonnet is consistent with his own theory of the nature and function of poetry. The definition he provides for poetry in his essay "An Answer to the Question 'What Is Poetry' " throws light on his poetics. According to Hunt, poetry

is the utterance of a passion for truth, beauty, and power, embodying and illustrating its conceptions by imagination and fancy, and modulating its language on the principle of variety in uniformity. Its means are whatever the universe contains; and its ends, pleasure and exaltation. (1)

In the course of the essay, Hunt expounds the poetics informing his poetry. He states that poetry is a passion "because it seeks the deepest impressions" (italics mine); it is a passion for beauty "because its office is to exalt and refine by means of pleasure, and because beauty is ... the loveliest form of pleasure;" and it is a passion for power "because power is impression triumphant, whether over the poet, as desired by himself, or over the reader, as affected by the poet" (1-2). Finally, Hunt asserts that the poet has to cultivate "love and truth" and to avoid "the fleeting and the false" (47).

The impression Hunt wants to communicate in his Nile sonnet is his dissatisfaction with policies of repression pursued by the ruling class in his time. Because the poet, in Hunt's view, has to avoid "the fleeting," and as the poet is motivated by his passion for truth, Hunt's political critique is expressed both by metaphor and by implication; the poem was not locked into the local and the particular and its message has been rendered universal. Drawing on the example of the ancient Egyptian civilization, Hunt could convey general truths regarding the transience of political power and the inevitability of change. River imagery is also utilized to represent, via simile, the workings of the poet's mind, and to instill hope, inspired by the continuous flow of the river, in the possibility of realizing dreams of reform. Furthermore, Hunt's sonnet accords with his premise that the purpose of poetry is to exalt and refine by means of pleasure. The poet engages readers in an aesthetic experience from which they derive pleasure and through which they achieve a better understanding of their historical conditions and recognize the importance of resisting silence and political oppression.

Hunt's poetics places emphasis on the sound of poetry as an important element of a poem's aesthetic dimension, and identifies the poet's reliance on indirection as part of the enjoyment afforded by poetry. In "What Is Poetry?", Hunt contends that poetry "modulates what it utters, because in running the whole round of beauty it must needs[sic] include beauty of sound; and because, in the height of its enjoyment, it must show the perfection of its triumph, and make difficulty itself 
become part of its facility and joy" (2). In addition to reinforcing the poem's message, Hunt's use of sound devices (sibilance in particular) adds to the poem's beauty of sound. And the political implications his poem imparts run through its content as an undercurrent that requires attentive reading to uncover; the sonnet reproduces poetically the political concerns that Hunt's essays in the Examiner represent explicitly. The sonnet abides by Hunt's assertion that "beauty and truth become identical in poetry, and that pleasure... is drawn out of pain" ("What Is Poetry?" 5).

To inspire in his audience the impressions and convictions he wants his sonnet to communicate, Hunt employs the three modes of persuasion on which the art of rhetoric is built. In Aristotle's Art of Rhetoric, these modes are termed ethos, pathos, and logos; they constitute the ethical, emotional, and logical proofs, or means of persuasion, devised by a speaker to convince an audience. The following is an English rendering of Aristotle's explication of the three terms in book I of the Art of Rhetoric:

Now the proofs furnished by the speech are of three kinds. The first depends upon the moral character of the speaker, the second upon putting the hearer into a certain frame of mind, the third upon the speech itself, in so far as it proves or seems to prove. (Aristotle 17)

Ethos, or the ability to persuade by moral character, rests on the speaker's credibility which arises from the manner in which his speech is delivered; it could be achieved through the appropriate use of language and syntax. In his Nile sonnet, Hunt utilizes a number of techniques which show his readers that he is a credible source and is worth listening to. At the poem's outset, words like "grave mighty thought," and "vision" lend gravity and significance to the ideas to be addressed in the sonnet. Throughout the sonnet, a tone of formality is sustained not only through the careful choice of diction and the remarks about "old" Egypt but also via reliance on a syntax characterized by the avoidance of fragments and inversions and the use of intricate sentence pattern.

Hunt also opts for a hypotactic writing style that depends on complex sentences in which phrases and clauses are coordinated or subordinated. Defined as "a grammatical arrangement of constructs that work in the same way, but which play unequal roles in a sentence," hypotaxis is used by writers to convey logical, causal, or temporal relationships within sentences; it is an effective device for argument and persuasion ("Hypotaxis"). Hunt's hypotactic style contributes effectively to the appeal to logic, or logos, which convinces the audience by constructing logical argument and using historical or literal analogies. 
Dwelling upon the historical example of the ancient Egyptian civilization, Hunt proves the impermanence of political power and the inevitableness of social as well as political change.

As regards the emotional appeal, or pathos, which makes the audience or readers feel what the speaker wants them to feel, Hunt achieves this end in the poem's sestet: first through the implied reference to his prison experience, which suggests that his firsthand experience of political oppression brought him and his readers in a common bond (metaphorically represented by his reference to "the void [which] weighs on $u s ")$; and second through asserting his determination to continue the journey towards freedom and reform that he began "for human sake." Thus, by forming an emotional bond with his readers, based on shared feelings and interests, Hunt could induce the desired impression upon those readers, which is to evoke in them the spirit of resistance.

Relevant to the poem's appeal to emotions is also the poet's attempt to put his readers in a more optimistic frame of mind. This is particularly clear in the sonnet's conclusion which is informed by Hunt's commitment to the "cause of cheerfulness," as the final tercet conveys and inspires feelings of hope as well as confidence. This rejection of despondency and the tendency to embrace hopefulness and optimism constitute a definitive feature of Hunt's poetics. Hunt expounds his philosophy of cheerfulness in the preface to the poetry collection entitled Foliage; or Poems Original and Translated (1818), where his Nile sonnet first appeared. In the "Preface" to Foliage, Hunt states that the original poems and translations in this volume "were written from the same love of nature, and in the same cause of cheerfulness" (30-31). The preface bears the subtitle "Cursory Observations on Poetry and Cheerfulness;" and it characterizes Hunt's poetry as primarily a response to "the political convulsions of the world" (10).

Hunt adheres to the kind of poetry which rejects the spirit of despair arising from the social and political circumstances of the day. $\mathrm{He}$ endorses a counter-cultural attitude encouraging pleasurable enjoyment, which he sees as "the end of virtue itself." Elaborating on his views in this regard, he writes:

The depreciators of this world ... have tried melancholy and partial systems enough, and talked enough of their own humility. It is high time for them, and for all of us, to look after health and sociality; and to believe, that although we cannot alter the world with an ipse dixit, we need not become desponding, or mistake a disappointed egotism for humility. ("Preface" to Foliage 15-16) 
Hunt's poetry is directed against despondency, and he is committed to the spirit of hope and cheerfulness in spite of the inconvenient political circumstances of the time. Squarely articulating this attitude, he writes: "my creed ... is not only hopeful, but cheerful; and I would pick the best parts out of other creeds too, sure that I was right in what I believed or chose to fancy, in proportion as I did honour to the beauty of nature and spread cheerfulness and a sense of justice among my fellow-creatures" ("Preface" to Foliage 16-17). Hunt's espousal of this creed of cheerfulness could be seen as part of a broader agenda for political and social reform, as hopelessness would avail people nothing. Written in complete obedience to his poetics of cheerfulness, Hunt's Nile sonnet aims at liberating people from disillusionment and keeping alive the hope of social and political change.

\section{Conclusion:}

Inspired by African explorations and utilizing the traditional Romantic association between the movement of the river and the processes of the mind, the Nile sonnets of Shelley, Keats, and Hunt convert material journeys into mental travel. In spite of the inwardness and psychological depth characterizing the three sonnets, the Romantic poets differ in the way they employed the potamography of the Nile River to communicate varying imaginative experiences which reflect their individual poetic personalities and reveal, within the compact territory of the sonnet form, their distinct approaches to poetry.

Determined to use his river poem as a vehicle for concretizing his view of the nature and function of the poet's creative faculty, Shelley constructs and develops an extended metaphor which exploits elements of the real topographical map of the Nile River to chart a map of poetic inspiration and imaginative creation. Shelley's "To the Nile," thus, becomes a metaphorical representation of his theory of poetry. However, the paradoxical nature of the Nile's trajectory elicited a different response from Keats, evoking fears of the inability to realize poetic ambitions to the full, and at the same time raising doubts about the fruitfulness of the Nile River whose course flows through the desert. Putting into practice his doctrine of "negative capability" which enables the poet to tolerate uncertainty and embrace ambiguity, Keats transcends the imperfections of the world and starts to perceive the beauties of the river and articulate them as truth. This imaginative openness of mind is an essential quality of the poet in Keats's view. Thus, Keats's "To the Nile" reflects his theory on poetic creativity. 


\section{Mona Salah El-Din Hassanein}

Hunt's treatment of the central figure in his Nile sonnet is different in that the Nile River and the civilization built along its banks are utilized as a tool for providing the historical and literary analogies, or logical and artistic proofs, devised by Hunt to impart the political message of his poem and to draw the readers into sympathy with the views his poem ingeniously conveys. The sequence of thought and emotion depicted in Hunt's "The Nile" is intended to inspire hopes of political and social reform. The poem's intended effect is enhanced not only by the modes of persuasion Hunt draws upon but also by the sound devices he employs. Hunt's poem blends beauty and truth and reflects his creed of cheerfulness. Like the two sonnets of Shelley and Keats, therefore, Hunt's Nile sonnet is expressive of its author's particular concerns and illustrative of his own philosophy of poetry. 


\section{Works Cited}

Abrams, M. H., et al., eds. The Norton Anthology of English Literature. $3^{\text {rd }}$ ed. Vol. 2. New York: W. W. Norton \& Company, 1974.

Allan, Janice. "The Other." The Routledge Dictionary of Literary Terms. Ed. Peter Childs and Roger Fowler. London: Routledge, 2006. 164-65.

Alvey, Nahoko Miyamato. 'Strange Truths in Undiscovered Lands': Shelley's Poetic Development and Romantic Geography. Toronto: U of Toronto P, 2009.

Applebee, Arthur N., et al. The Language of Literature: British Literature. Evanston: McDougal Littell, 1997.

Aristotle. The "Art" of Rhetoric. Trans. John Henry Freese. The Loeb Classical Library. London: William Heinemann, 1926.

Ashcroft, Bill, Gareth Griffiths, and Helen Tiffin. Post-Colonial Studies: The Key Concepts. $2^{\text {nd }}$ ed. London: Routledge, 2007.

Bate, Walter Jackson. John Keats. Cambridge: Belknap Press of Harvard UP, 1963.

- - -. Prefaces to Criticism. New York: Doubleday and Company, 1959.

Bhabha, Homi K. The Location of Culture. London: Routledge, 1994.

Darwish, Hala Y. "Ancient Egypt as Metaphor in Nineteenth-Century English Poetry: A New Historicist Reading of Three Sonnets." Egypt at the Crossroads: Literary and Linguistic Studies. Proceedings of the $9^{\text {th }}$ International Symposium on Comparative Literature, Cairo University, The Department of English Language and Literature, 4-6 Nov. 2008. Ed. Salwa A. Kamel, Hoda S. Gindi, and Nadia S. El-kholi. Cairo: Hussein Abdel-Aziz \& Co. Printing Press, 2009. 265-80.

Feldman, Paula R. and Daniel Robinson. Introduction. A Century of Sonnets: The Romantic-Era Revival 1750-1850. Ed. Paula R. Feldman and Daniel Robinson. New York: Oxford UP, 1999. 3-19.

Fulford, Tim, Debbie Lee, and Peter J. Kitson. Literature, Science and Exploration in the Romantic Era: Bodies of Knowledge. Cambridge Studies in Romanticism. Cambridge: Cambridge UP, 2004. 
Hunt, Leigh. "An Answer to the Question 'What is Poetry?' " Imagination and

Fancy; or, Selections from the English Poets, Illustrative of Those First

Requisites of Their Art; with Markings of the Best Passages, Critical Notices of the Writers, and an Essay in Answer to the Question "What is Poetry?." By Leigh Hunt. London: Smith, Elder\& Co., 1891. 1-48.

- - - "The Nile." 1818. The Poetical Works of Leigh Hunt. Ed. Thornton Hunt. London: Routledge, 1860. 235.

- - - Preface. Foliage; or Poems Original and Translated. By Leigh Hunt. London: C. and J. Ollier, 1818. 9-39.

"Hypotaxis." Accessed 9 April 2019 from: literarydevices. net

Keats, John. Letters of John Keats: A Selection. Ed. Robert Gittings. Oxford Paperbacks. Oxford: Oxford UP, 1977.

- - - . "To the Nile." 1838. The Poems of John Keats. Ed. Miriam Allott. A Longman Paperback. London: Longman, 1970. 307-08.

Lee, Debbie. Slavery and the Romantic Imagination. Philadelphia: U of Pennsylvania P, 2002.

Masson, David. "The Life and Poetry of Keats." Macmillan's Magazine III (November 1860): 1-16. Rpt. in Keats: The Critical Heritage. Ed. G. M. Matthews. London: Routledge \& Kegan Paul, 1971. 368-83.

"Nile River." Encyclopedia Britannica. Accessed 24 Jan. 2018 from: www. britannica. com / place /Nile-River

Roe, Nicholas. Introduction: Leigh Hunt's Track of Radiance. Leigh Hunt: Life, Poetics, Politics. Ed. Nicholas Roe. London: Routledge, Taylor \& Francis e-Library, 2004. 1-18.

Schlegel, Chris. "Sibilance." Litcharts. LitCharts LLC, 5 May 2017. Accessed 27 July 2018 from: www. Litcharts. com / literary-devices-and-terms / sibilance. N. pag.

Shelley, Percy Bysshe. A Defence of Poetry. 1840. Ed. Mrs. Shelley. Indianapolis: The Bobbs-Merrill Company, 1904.

- - - "To the Nile." 1876. Shelley: Poetical Works. Ed. Thomas Hutchinson. Oxford Standard Authors. London: Oxford UP, 1975. 552. 
"Sibilance." Accessed 8 Sept. 2018 from: sibilance <www. literarydevices. com

"Sibilant." Encyclopedia Britannica. Accessed from: www. britannica. com

Staszak, Jean-François. "Other / Otherness." International Encyclopedia of Human Geography. Ed. Barney Warf. Thousand Oaks: Sage Publication, 2010. Accessed 26 Feb. 2018 from: www. unige. ch / Sciences-Societe / geo / files / 3214/ 4464 / 7634 / Other Otherness. pdf

Thomas, Sophie. "Displaying Egypt: Archaeology, Spectacle, and the Museum in the Early Nineteenth Century." Journal of Literature and Science 5.1 (2012): 6-22.

Tovey, Paige. The Transatlantic Eco-Romanticism of Gary Snyder. The New Urban Atlantic. New York: Palgrave Macmillan, 2013.

Wolosky, Shira. The Art of Poetry: How to Read a Poem. Oxford: Oxford UP, 2001.

Wu, Duncan. "The Riparian Muse." Romanticism: An Anthology. Blackwell, 1998. Accessed from: romantic-circles. org. N. pag. 